Part I. Diseases and problems distinguished by WHO and FAO

Dział I. Choroby i problemy wyróżnione przez WHO i FAO

\title{
THE RELATIONSHIP BETWEEN EMOTIONAL STATE AND THE CONSUMPTION OF FOODS RICH IN CARBOHYDRATES BY YOUNG ADULTS
}

\section{ZWIĄZEK MIĘDZY STANEM EMOCJONALNYM A KONSUMPCJĄ PRODUKTÓW BOGATYCH W WĘGLOWODANY PRZEZ MEODYCH DOROSEYCH}

\section{Mariusz Jaworski ${ }^{1,2(A, C, D, E, F, G)}$, Marta Izabela Szatańska ${ }^{3(B, C, D, E, F)}$, Sylwia Sawicka ${ }^{3(B, C, D, E)}$}

${ }^{1}$ Department of Medical Psychology, Medical University of Warsaw, Poland

${ }^{2}$ Warsaw School of Tourism and Hospitality Management, Vistula Group of Universities, Poland

${ }^{3}$ Student Scientific Circle Research on Eating Disorders (SKNBnZO) at the Department of Medical Psychology,

Medical University of Warsaw, Poland

\author{
Authors' contribution \\ Wkład autorów: \\ A. Study design/planning \\ zaplanowanie badań \\ B. Data collection/entry \\ zebranie danych \\ C. Data analysis/statistics \\ dane - analiza i statystyki \\ D. Data interpretation \\ interpretacja danych \\ E. Preparation of manuscript \\ przygotowanie artykułu \\ F. Literature analysis/search \\ wyszukiwanie i analiza literatury \\ G. Funds collection \\ zebranie funduszy
}

\begin{abstract}
Summary
Background. High intake of carbohydrates, especially simple sugars, by young adults is associated with the consumption of highly processed foods. This leads to the development of overweight, obesity and various somatic diseases. Identification of factors contributing to the increased consumption of this product group is a very important area of research in the field of public health. Emotional state may be one of such factors. This research aims at analyzing the relationship between consumption of selected groups of foods rich in carbohydrates and actual affective states on the one hand, and relatively constant emotional features on the other hand, in case of young adults.

Material and methods. The study was conducted among 120 young adults aged between 18 and to 38 years old. The questionnaire research method, combined with prospective evaluation of diets technique, was used in the study. Two research instruments were used in the research: the scale of positive and negative feelings and food intake frequency questionnaire FQQ.

Results. Our research confirmed the relationship between both affective state and relatively constant emotional features with consumption of selected products groups containing carbohydrates, especially simple sugars and glycogen, both in case of women and men. The said relationship has been demonstrated both in case of positive and negative emotions. The study did not confirm the relationship between affective state and consumption of chocolate. Conclusions. The observed relations can be used in the prevention of first degree, taking into account gender differences. It can also be used in potential therapeutic interactions, especially in the field of proper nutrition.
\end{abstract}

Keywords: emotional state, nutrition, emotions, obesity, simple sugars, chocolate, glycogen, carbohydrates

\section{Streszczenie}

Wprowadzenie. Wysokie spożycie cukrów prostych przez młodych dorosłych związane jest z konsumpcją wysoko przetworzonej żywności. Prowadzi to do rozwoju nadwagi i otyłości oraz licznych chorób somatycznych. Identyfikacja czynników przyczyniających się do zwiększonej konsumpcji tej grupy produktów stanowi bardzo ważny obszar badań z zakresu zdrowia publicznego. Jednym z takich czynników może być stan afektywny jednostki. Celem pracy jest analiza związu między konsumpcja wybranych grup produktów spożywczych bogatych w cukry proste i aktualnymi stanami afektywnymi z jednej strony, oraz względnie stałymi cechami afektywnymi jednostki z drugiej strony przez młodych dorosłych.

Materiał i metody. Badanie zostało przeprowadzone wśród 120 młodych dorosłych w wieku od 18 do 40 lat. W badaniu zastosowano metodę badań kwestionariuszowych połączoną z prospektywną techniką oceny sposobu odżywiania się. Zastosowano dwa narzędzia badawcze: skale uczuć pozytywnych i negatywnych SUPIN oraz kwestionariusz częstotliwości spożycia żywności FQQ. Wyniki. Wyniki badań potwierdziły związek między zarówno aktualnym stanem afektywnym jak i względnie stałymi cechami afektywnymi, a konsumpcja wybranych grup produktów zawierających cukry proste w przypadku kobiet jak i mężczyzn. Omawianą zależność wykazano zarówno w przypadku emocji pozytywnych, jak i negatywnych. Badania nie potwierdziły zwiazku miedzy stanem afektywnym a konsumpcją czekolady.

Wnioski. Wykazane zależności mogą mieć zastosowanie w profilaktyce pierwszego stopnia po uwzględnieniu różnic płciowych. Mogąbyć także wykorzystanew potencjalnych oddziaływaniach terapeutycznych, zwłaszcza z zakresu prawidłowego odżywiania się.

Słowa kluczowe: stan afektywny, żywienie, emocje, otyłość, cukry proste, czekolada
Figures: 3

References: 25

Submitted: 12.05 .2015

Accepted: 16.02.2016

Jaworski M, Szatanska MI, Sawicka S. The relationship between emotional state and the consumption of foods rich in carbohydrates by young adults. Health Problems of Civilization 2016; 10(2): 10-19. doi: 10.5114/hpc.2016.59628.

Address for correspondence / Adres korespondencyjny: Mariusz Jaworski, Department of Medical Psychology, Medical University of Warsaw, Żwirki i Wigury 81A, 02-091 Warszawa, e-mail: mariusz.jaworski@onet.pl, phone: +48 225720533

Copyright: @ 2016 Pope John Paul II State School of Higher Education in Biała Podlaska. This is an Open Access journal, all articles are distributed under the terms of the Creative Commons Attribution-NonCommercial-ShareAlike 4.0 International (CC BY-NC-SA 4.0) License (http://creativecommons.org/licenses/by-nc-sa/4.0/), allowing third parties to copy and redistribute the material in any medium or format and to remix, transform, and build upon the material, provided the original work is properly cited and states its license. 


\section{Background}

Carbohydrates can be divided into complex carbohydrates (oligosachrydy, polysaccharides) and simple carbohydrates (monosaccharides and disaccharides). There are two types of carbohydrates in terms of their importance in the diet. These are added sugars (sugars added to a food in the manufacture and production process, such as sucrose, fructose, glucose) and starch hydrolysates (e.g., high fructose or glucose syrups) [1].

Carbohydrates are the main source of the energy requirements of the body and determine the proper functioning of the brain. Glucose is an energy material for the brain. Excessive consumption of simple sugars can contribute to the development of diet-related diseases, among others, obesity and diabetes [2]. The fruits, vegetables, fruit and vegetable juices, dairy products are the main source of simple sugars in the diet. Sugars are often added during the technological process, especially saccharose. This simple sugar is added to the carbonated soft drinks, sweets and pastry products [2,3].

A high intake of simple sugars by young adults most likely is the result of frequent consumption of highly processed foods (eg, pastry products), sweetened soft drinks and sweets $[3,4,5]$. This is related to incorrect eating behaviour. The excessive intake of simple sugars may contribute to the development of overweight and obesity. Overweight and obesity are associated with many medical complications, particularly cardiologic and metabolic disorders $[5,6,7]$.

Currently, there are a number of educational campaigns regarding the healthy diet. Most of these programs are meant to increase nutrition knowledge in the population and prevent the development of diet-related diseases. Some of them are conducted on the Internet [8].

The one of the key problems of modern science of healthy humans is identification of factors that can contribute directly and indirectly to the development incorrect eating habits. This approach requires the integration connections achievements of many sciences, including psychology, health promotion and medicine.

The human's emotional state may be one of the factors which affect the intake of carbohydrates, especially simple sugars. There are a number of studies which have shown relationship between emotions and food consumption $[9,10,11]$. The analysis of the relationship between positive emotional state and eating behaviour was not tested too often.

There is a perception in literature that emotional eating concerns food consumption under the influence of negative emotions [12]. This theory did not include or discard the importance of positive emotions in the eating habits. It persisted for many years. Many studies have identified negative and positive emotions as opposed to the dimensions of the same continuum. It is a wrong assumption. Low severity of negative emotions does not mean a high concentration of positive emotions.

According to the concept by D. Watson and A. Teliega positive and negative feelings should be considered as two independent dimensions. The authors point out that emotions may relate to the current situation (current emotional state) or be predisposed to experiencing the emotions with the specified character (relatively stable emotional traits). The differentiation of these dimensions is important in terms of personality and / or temperament profile analysis. And also, it has an impact on mental health and somatic [13].

A better understanding of the role of emotions in the eating behaviour needs of differentiation of the current emotional state and relatively stable emotional characteristics. The differentiation of relationship eating habits and current affective states on the one hand and relatively constant emotional characteristics on the other hand becomes essential in this context.

The purpose of this study is to analyze the relationship between consumption of selected groups of foods rich in carbohydrates - especially in simple sugars and glycogen- and the current emotional states on the one hand and relatively constant emotional traits on the other hand among young adults. This article is meant to define the role of emotional states and characteristics in eating behaviour. Positive and negative emotions were included in this study.

We formulated the following research hypotheses in relation to the basic aim of this research:

1. Have the current emotional states (positive and negative) a relationship with the consumption of foods rich in carbohydrates - especially in simple sugars and glycogen - in young adults?

2. Have the relatively constant emotional features (positive and negative) a relationship with the consumption of foods rich in carbohydrates - especially in simple sugars and glycogen - in young adults?

3. Are there gender differences in terms of the relationship between current emotional state (positive and negative) and consumption of foods rich in carbohydrates - especially in simple sugars and glycogen - in young adults?

4. Are there gender differences in terms of the relationship between the relatively constant emotional features (positive and negative) and the consumption of foods rich in carbohydrates - especially in simple sugars and glycogen - in young adults? 
A theoretical model of the relationship between the consumption of foods rich in carbohydrates - especially in simple sugars and glycogen - and the current emotional state on the one hand and relatively constant emotional traits on the other hand was developed. According to this model relatively constant emotional characteristics affect the emotional expression of the current emotional state, which may affect the frequency of consumption of foods rich in carbohydrates. The relatively constant emotional characteristics can also have a direct impact on the frequency of products containing sugars consumption (Scheme 1). We assumed an equivalent impact both relatively constant positive and negative emotional characteristics in our model. This is an innovation of this study.

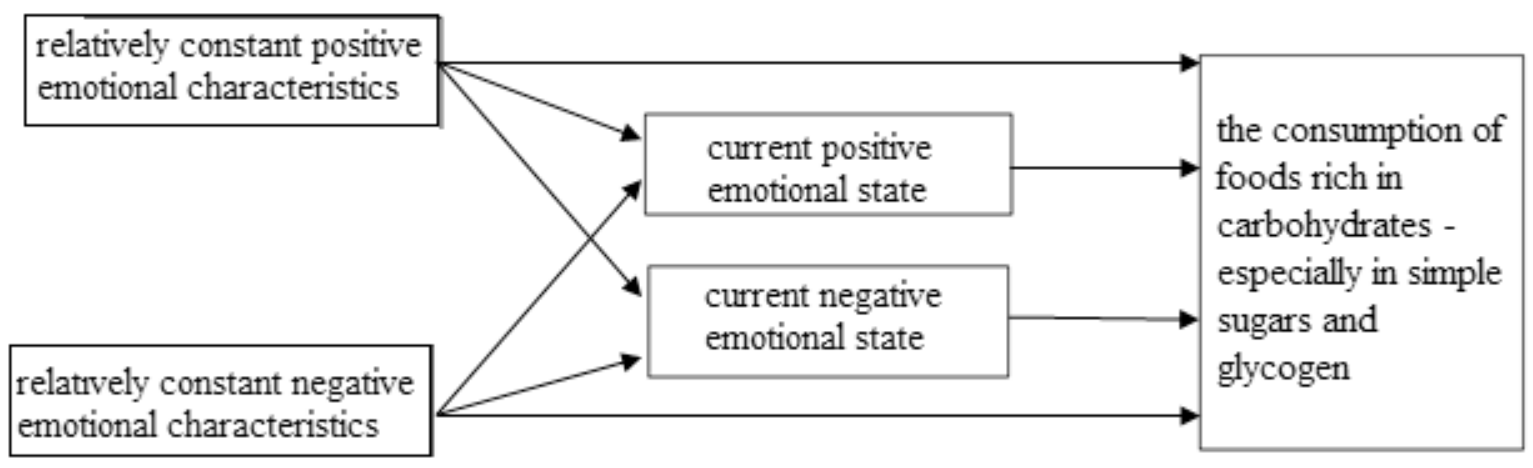

Figure 1. Theoretical model of the relationship between the analyzed variables

\section{Material and methods}

The study group consisted of 120 purposefully chosen respondents ( 60 were female and 60 were male). The subjects were recruited from patients who were:

1. Age between 18 and 40. This criterion was developed based on Erikson's psychosocial development concept. This is the period in which the individual personality is already formed.

2. Gender.

3. Gave informed consent to be part of the study. All patients gave informed consent.

4. Body mass index BMI (Body Mass Index) in the normal range (ie, 18,9-24, 9kg/m2). The BMI was calculated and interpreted in accordance with the guidelines of the WHO (World Health Organization).

The research questionnaire method combined with prospective technique for the assessment diet was used in research. The research was conducted from the perspective of respondents involved in the project. Two research tools were used:

1. The Scale of Positive and Negative Feelings - SUPINE by David Watson and Lee Anna Clark in Polish adaptation by Piotr Brzozowski,

2. Food Intake Frequency Questionnaire (FQQ) by Lidia Wądołowska.

The Scale of Positive and Negative Feelings - SUPINE by David Watson and Lee Anna Clark in Polish adaptation by Piotr Brzozowski was used in study. SUPINE tool is used to measure the intensity of negative and positive emotions. It is designed to measure the current emotional states and permanent emotional features. It has four different versions. Each version has the form of list of adjectives. The results shall be calculated separately for the two subscales - PU (positive feelings) and NU (negative emotions). Alpha Cronbach's coefficients of this subscales are in the range of 0.73 to 0.95 . Validity and reliability of the questionnaire is satisfactory [14].

The Food Intake Frequency Questionnaire (FQQ) by Lidia Wądołowska was used in this study. The FFQ is a semi-quantitative food intake frequency questionnaire. FFQ is an advanced tool which allows you to assess the frequency (times / person / day) and quantity (g / person / day) of food customarily consumed per year. FFQ validation studies are actually conducted. These studies are aimed at develop a procedure for estimating the energy value and nutrition declaration normal food rations. The respondents evaluated the frequency of consumption of various food groups using 6-point scale (1 - never or almost never, 2 - Once a month or less, 3 - a few times a month, 4 - few times a week, 5 - everyday, 6 - few times a day) [15]. The following product groups were analyzed:

1. sugar used to sweeten beverages,

2. honey used to sweeten foods and beverages, 
3. Chocolate, chocolate candies and bars,

4. no chocolate candy, for example, fruit candies, caramels, jelly beans, fudge, toffee,

5. Biscuits and cakes;

6. Ice cream and pudding;

7. Sweetened Beverages.

Respondents taking part in this research filled up the all FQQ questionnaire although for the purposes of this research analyzed only the frequency of consumption of foods rich in carbohydrates - especially in simple sugars and glycogen. This procedure was used to ensure the correctness of the methodological. This approach are meant to partial masking the main purpose of the study and obtain a more reliable results.

Statistical analysis was performed using statistical package Statistica 9.0. The criterion for statistical significance was set at $p \leq 0.05$. The Spearman's rank correlation coefficient is used to examination the relation between the analyzed variables. Advanced structural equation models were developed using AMOS 21.0. The structural equation analysis (SEM) was used in this study. This method allows to assess the impact of one variable in relation with another one, and therefore refers to the direction of the relationship. The standardized path coefficient values was used in the present study. This coefficient informs how change the variables which is effect if the variables which is cause changes by one unit.

\section{Results}

The mean age of respondents taking part in the study was $23.2 \pm 3.7$ years old. All study subjects were divided into two groups in terms of gender.

The first group consisted of 60 women aged 18 to 38. The mean age of women participating in the study was 22.9 years $(\mathrm{SD}=3.58)$. The second group consisted of 60 men aged 18 to 37 . The mean age of men in the study was 23.87 years $(\mathrm{SD}=3.86)$. There were no statistically significant differences between the analyzed groups with respect to age by using the Student's $t$-test for two independent groups $(t=-0.74, p=0.46)$.

The analyzed groups differed in the current body weight $(\mathrm{t}=-14.53, \mathrm{P}<0.01)$ and BMI coefficient value $(\mathrm{t}$ $=-3.94, \mathrm{p}<0.01)$. The average weight was $56.12 \mathrm{~kg}(\mathrm{SD}=6.10)$ for women and $73.47 \mathrm{~kg}(\mathrm{SD}=6.95)$ for men participating in the study. The mean BMI value among women $(20.47 \pm 1.66)$ was lower than in men $(22.45 \pm$ 3.52).

The study showed no statistically significant differences between women and men in terms of current positive $(\mathrm{t}=-1.36, \mathrm{p}>0.05)$ and negative $(\mathrm{t}=0.53, \mathrm{p}>0.05)$ emotional states by using comparative analysis (Table 1 ). The similar analysis results were obtained in terms of relatively constant emotional features. Women did not differ from men in terms of both relatively constant positive emotional features $(t=-1.27, p>0.05)$ and relatively constant negative emotional features $(t=-1.71, p>0.05)$ (Table 1$)$.

Table 1. Characteristics of the studies groups in terms of affective states and features

\begin{tabular}{|c|c|c|c|c|c|}
\hline & Group & M & SD & t & $\mathbf{p}$ \\
\hline \multirow{2}{*}{ The current positive affective states } & 1 & 6.38 & 2.16 & \multirow{2}{*}{-1.36} & \multirow{2}{*}{0.18} \\
\hline & 2 & 6.97 & 2.54 & & \\
\hline \multirow{2}{*}{ The current negative affective states } & 1 & 5.75 & 3.03 & \multirow{2}{*}{0.53} & \multirow{2}{*}{0.60} \\
\hline & 2 & 5.52 & 1.62 & & \\
\hline \multirow{2}{*}{$\begin{array}{l}\text { The relatively constant positive emotional } \\
\text { features }\end{array}$} & 1 & 7.32 & 2.01 & \multirow{2}{*}{-1.27} & \multirow{2}{*}{0.21} \\
\hline & 2 & 7.78 & 2.00 & & \\
\hline \multirow{2}{*}{$\begin{array}{l}\text { The relatively constant negative emotional } \\
\text { features }\end{array}$} & 1 & 4.40 & 1.44 & \multirow{2}{*}{-1.71} & \multirow{2}{*}{0.09} \\
\hline & 2 & 4.85 & 1.44 & & \\
\hline
\end{tabular}

Group 1 - women, Group 2 - men, M - mean, SD - Standard deviation, t-Student's t test, p-statistical significance

The men declared more often sweetened beverages consumption compared to women. This observed differences were statistically significant $(t=-2.89, \mathrm{p}<0.05)$. There are no statistically significant differences in the case of other analyzed food products groups (Table 2).

Table 2. The comparative analysis of the declared frequency of selected product groups consumption.

\begin{tabular}{|l|c|c|c|c|c|}
\hline & Group & M & SD & t & p \\
\hline \multirow{2}{*}{ Sugar used to sweeten beverages } & 1 & 3.52 & 1.96 & \multirow{2}{*}{-0.87} & \multirow{2}{*}{0.39} \\
\cline { 2 - 4 } & 2 & 3.82 & 1.84 & & \\
\hline
\end{tabular}




\begin{tabular}{|c|c|c|c|c|c|}
\hline \multirow{2}{*}{ Honey used to sweeten foods and beverages } & 1 & 1.97 & 1.19 & \multirow{2}{*}{-0.25} & \multirow{2}{*}{0.81} \\
\hline & 2 & 2.02 & 1.03 & & \\
\hline \multirow{2}{*}{ Chocolate, chocolate candies and bars } & 1 & 3.63 & 1.19 & \multirow{2}{*}{0.41} & \multirow{2}{*}{0.69} \\
\hline & 2 & 3.55 & 1.05 & & \\
\hline \multirow{2}{*}{$\begin{array}{l}\text { No chocolate candy, for example, fruit can- } \\
\text { dies, caramels, jelly beans, fudge, toffee }\end{array}$} & 1 & 2.70 & 1.14 & \multirow{2}{*}{1.23} & \multirow{2}{*}{0.22} \\
\hline & 2 & 2.45 & 1.08 & & \\
\hline \multirow{2}{*}{ Biscuits and cakes } & 1 & 2.97 & 1.01 & \multirow{2}{*}{0.59} & \multirow{2}{*}{0.56} \\
\hline & 2 & 2.87 & 0.85 & & \\
\hline \multirow{2}{*}{ Ice cream and pudding } & 1 & 2.17 & 0.75 & \multirow{2}{*}{-0.43} & \multirow{2}{*}{0.67} \\
\hline & 2 & 2.23 & 0.87 & & \\
\hline \multirow{2}{*}{ Sweetened Beverages } & 1 & 2.32 & 1.27 & \multirow{2}{*}{-2.89} & \multirow{2}{*}{0.01} \\
\hline & 2 & 2.93 & 1.06 & & \\
\hline
\end{tabular}

Group 1 - women, Group 2 - men, M- mean, SD- Standard deviation, t-Student's t test, p-statistical significance

The frequency of ice cream and puddings consumption showed a significant correlation with the current positive emotional state ( $r h o=0.21, \mathrm{p}<0.05$ ). These dependence were not observed in the case of the declared frequency of sugar, honey, chocolate, candy, candy bars, biscuits and sweetened beverages consumption (Table 3 ). The current negative emotional state negatively correlated with the declared consumption of cakes and biscuits (rho $=-0.15, \mathrm{p}<0.05$ ). There were no statistically significant correlation with the current negative affection status in case of the other analyzed frequency of selected food groups consumption (Table 3).

The statistically significant associations relatively constant emotional features with the declared use honey to sweeten foods or beverages on the one hand, and cakes and biscuits consumption on the other hand was demonstrated in this study. The frequency of honey use to sweeten foods and beverages positively correlated with a relatively constant positive emotional features ( $r h o=0.21, \mathrm{p}<0.05$ ). The cakes and biscuits consumption showed a negative correlation with a relatively constant negative emotional features ( $\mathrm{rho}=-0.23, \mathrm{p}<0.01$ ). there were no statistically significant relationship with relatively constant emotional features with other analyzed food groups (Table 3).

Table 3. Relationships between emotional state and the consumption of selected food groups

\begin{tabular}{|c|c|c|c|c|c|c|c|c|}
\hline & & $\begin{array}{l}\text { Sugar used } \\
\text { to sweeten } \\
\text { beverages }\end{array}$ & $\begin{array}{c}\text { Honey } \\
\text { used to } \\
\text { sweeten } \\
\text { foods and } \\
\text { beverages }\end{array}$ & $\begin{array}{l}\text { Chocolate, } \\
\text { chocolate } \\
\text { candies } \\
\text { and bars }\end{array}$ & $\begin{array}{c}\text { No choco- } \\
\text { late candy, } \\
\text { for exam- } \\
\text { ple, fruit } \\
\text { candies, } \\
\text { caramels, } \\
\text { jelly beans, } \\
\text { fudge, } \\
\text { toffee } \\
\end{array}$ & $\begin{array}{c}\text { Biscuits } \\
\text { and cakes }\end{array}$ & $\begin{array}{l}\text { Ice cream } \\
\text { and pud- } \\
\text { ding }\end{array}$ & $\begin{array}{l}\text { Sweetened } \\
\text { Beverages }\end{array}$ \\
\hline \multirow{2}{*}{$\begin{array}{l}\text { The current positi- } \\
\text { ve affective states }\end{array}$} & rho & -0.07 & 0.15 & 0.04 & 0.12 & 0.02 & 0.21 & 0.13 \\
\hline & $\mathrm{p}$ & 0.23 & 0.05 & 0.32 & 0.10 & 0.43 & 0.01 & 0.07 \\
\hline \multirow{2}{*}{$\begin{array}{l}\text { The current negati- } \\
\text { ve affective states }\end{array}$} & rho & 0.09 & -0.05 & 0.09 & 0.02 & -0.15 & -0.09 & 0.03 \\
\hline & $\mathrm{p}$ & 0.18 & 0.29 & 0.16 & 0.41 & 0.04 & 0.17 & 0.39 \\
\hline \multirow{2}{*}{$\begin{array}{c}\text { The relatively } \\
\text { constant positive } \\
\text { emotional features }\end{array}$} & rho & -0.02 & 0.21 & -0.07 & 0.04 & -0.04 & 0.10 & 0.04 \\
\hline & $\mathrm{p}$ & 0.49 & 0.01 & 0.23 & 0.32 & 0.32 & 0.14 & 0.31 \\
\hline \multirow{2}{*}{$\begin{array}{c}\text { The relatively } \\
\text { constant negative } \\
\text { emotional features }\end{array}$} & rho & 0.08 & -0.08 & -0.06 & -0.12 & -0.23 & -0.01 & 0.06 \\
\hline & $\mathrm{p}$ & 0.18 & 0.20 & 0.27 & 0.12 & 0.01 & 0.48 & 0.26 \\
\hline
\end{tabular}

rho - Spearman correlation coefficient, $\mathrm{p}$ - level of statistical significance

The declared frequency of biscuits and cookies consumption by women showed a positive correlation with the current positive emotional state (rho $=-0.22, \mathrm{p}<0.05$ ) and positively with the current negative affective states (rho $=0.24, \mathrm{p}<0.05$ ), as well as a relatively constant negative affective features (rho $=0.20, \mathrm{p}<0.05$ ). There were no such relationship in case of the other analyzed product groups (Table 4). A slightly different observation were noted for men. The sugar use to the sweeten beverages negatively correlated with the current positive emotional state among men (rho $=-0.21, \mathrm{p}<0.05)$. The honey use to sweeten foods and beverages was 
characterized by a relatively positive permanent features in men (rho $=0.25, \mathrm{p}<0.05$ ). The frequency of cakes and biscuits consumption showed a negative relationship with relatively constant negative emotional features in the case of a male (rho $=-0.27, \mathrm{p}<0.05$ ). There were no such relationship in the case of current positive and negative emotional states. It was interesting to obtain statistically significant results which showed a positive correlation between the ice-cream consumption of ice-cream and the positive emotional state (rho $=0.24, p$ $<0.05$ ) on the one hand and a negative emotional state (rho $=-0.23, \mathrm{p}<0.05$ ) on the other hand among men. This dependence has not been demonstrated among women (Table 4).

Table 4. The relationship between emotional states/features with selected product groups consumption for women and men

\begin{tabular}{|c|c|c|c|c|c|c|c|c|c|}
\hline & & & $\begin{array}{c}\text { Sugar } \\
\text { used to } \\
\text { sweeten } \\
\text { beverages }\end{array}$ & $\begin{array}{c}\text { Honey } \\
\text { used to } \\
\text { sweeten } \\
\text { foods and } \\
\text { beverages }\end{array}$ & $\begin{array}{c}\text { Chocolate, } \\
\text { chocolate } \\
\text { candies } \\
\text { and bars }\end{array}$ & \begin{tabular}{|c|} 
No choco- \\
late candy, \\
for exam- \\
ple, fruit \\
candies, \\
caramels, \\
jelly be- \\
ans, fudge, \\
toffee \\
\end{tabular} & $\begin{array}{l}\text { Biscuits } \\
\text { and cakes }\end{array}$ & $\begin{array}{l}\text { Ice cream } \\
\text { and pud- } \\
\text { ding }\end{array}$ & $\begin{array}{l}\text { Sweete- } \\
\text { ned Beve- } \\
\text { rages }\end{array}$ \\
\hline \multirow{8}{*}{ 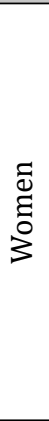 } & \multirow{2}{*}{$\begin{array}{l}\text { The current positi- } \\
\text { ve affective states }\end{array}$} & rho & 0.04 & 0.15 & 0.08 & 0.14 & -0.22 & 0.17 & 0.02 \\
\hline & & $\mathrm{p}$ & 0.40 & 0.13 & 0.26 & 0.15 & 0.04 & 0.10 & 0.43 \\
\hline & \multirow{2}{*}{$\begin{array}{l}\text { The current negati- } \\
\text { ve affective states }\end{array}$} & rho & 0.04 & -0.08 & 0.08 & 0.10 & 0.24 & 0.08 & 0.04 \\
\hline & & $\mathrm{p}$ & 0.39 & 0.29 & 0.28 & 0.23 & 0.03 & 0.27 & 0.38 \\
\hline & \multirow{2}{*}{$\begin{array}{c}\text { The relatively } \\
\text { constant positive } \\
\text { emotional features }\end{array}$} & rho & -0.01 & 0.14 & -0.07 & 0.01 & 0.06 & 0.09 & -0.03 \\
\hline & & $\mathrm{p}$ & 0.46 & 0.14 & 0.29 & 0.50 & 0.50 & 0.24 & 0.42 \\
\hline & \multirow{2}{*}{$\begin{array}{c}\text { The relatively } \\
\text { constant negative } \\
\text { emotional features }\end{array}$} & rho & 0.04 & -0.07 & -0.02 & -0.10 & 0.20 & 0.15 & 0.06 \\
\hline & & $\mathrm{p}$ & 0.38 & 0.30 & 0.43 & 0.24 & 0.04 & 0.13 & 0.33 \\
\hline \multirow{8}{*}{$\sum^{\Xi}$} & \multirow{2}{*}{$\begin{array}{l}\text { The current positi- } \\
\text { ve affective states }\end{array}$} & rho & -0.21 & 0.13 & 0.02 & 0.13 & -0.12 & 0.24 & 0.15 \\
\hline & & $\mathrm{p}$ & 0.04 & 0.16 & 0.44 & 0.17 & 0.17 & 0.03 & 0.13 \\
\hline & \multirow{2}{*}{$\begin{array}{l}\text { The current negati- } \\
\text { ve affective states }\end{array}$} & rho & 0.12 & -0.04 & 0.12 & -0.03 & -0.06 & -0.23 & -0.03 \\
\hline & & $\mathrm{p}$ & 0.17 & 0.39 & 0.19 & 0.40 & 0.32 & 0.04 & 0.40 \\
\hline & \multirow{2}{*}{$\begin{array}{c}\text { The relatively } \\
\text { constant positive } \\
\text { emotional features }\end{array}$} & rho & -0.01 & 0.25 & -0.08 & 0.20 & -0.19 & 0.12 & 0.03 \\
\hline & & $\mathrm{p}$ & 0.46 & 0.03 & 0.27 & 0.18 & 0.07 & 0.18 & 0.42 \\
\hline & \multirow{2}{*}{$\begin{array}{c}\text { The relatively } \\
\text { constant negative } \\
\text { emotional features }\end{array}$} & rho & 0.11 & -0.11 & -0.09 & -0.09 & -0.27 & -0.16 & 0.01 \\
\hline & & $\mathrm{p}$ & 0.21 & 0.20 & 0.25 & 0.24 & 0.02 & 0.11 & 0.47 \\
\hline
\end{tabular}

rho - Spearman correlation coefficient, $\mathrm{p}$ - level of statistical significance

It have shown that the BMI value positively correlates with the frequency of sweetened beverages consumption among women in this study (rho $=0.23, \mathrm{p}<0.05$ ). In contrast, this observations are for men. The men's BMI negatively correlated with the declared frequency of the sugar use to sweeten beverages $(\mathrm{rho}=-0.27, \mathrm{p}<0.05)$ and positively with the honey use to sweeten foods and beverages (rho $=0.24, p<0.05$ ). It was not observed in the case of women. It did not show dependence between the BMI and chocolate or chocolate products consumption among women (rho $=-0.05, \mathrm{p}>0.05$ ), as well as men ( $\mathrm{rho}=-0.16, \mathrm{p}>0.05$ ).

The relatively constant negative emotional features among women has a direct positively impact on the frequency of ice cream and pudding consumption. This negative emotional features have both direct and indirect negative impact on the frequency of cakes and biscuits consumption among women. The relatively constant positive affective features among women are characterized by both direct and indirect effects on frequency of cakes and biscuits consumption. There were no impact positive emotional features on the frequency of ice cream consumption among women. The developed model of the relationship between consumption of selected products groups (ice cream, cakes and biscuits) and current emotional states on the one hand and relatively constant emotional features on the other hand shows mutual constellation of positive and negative emotions. Results showed that positive and negative emotions among women complement each other and constitute a separate dimensions (Scheme 2). 


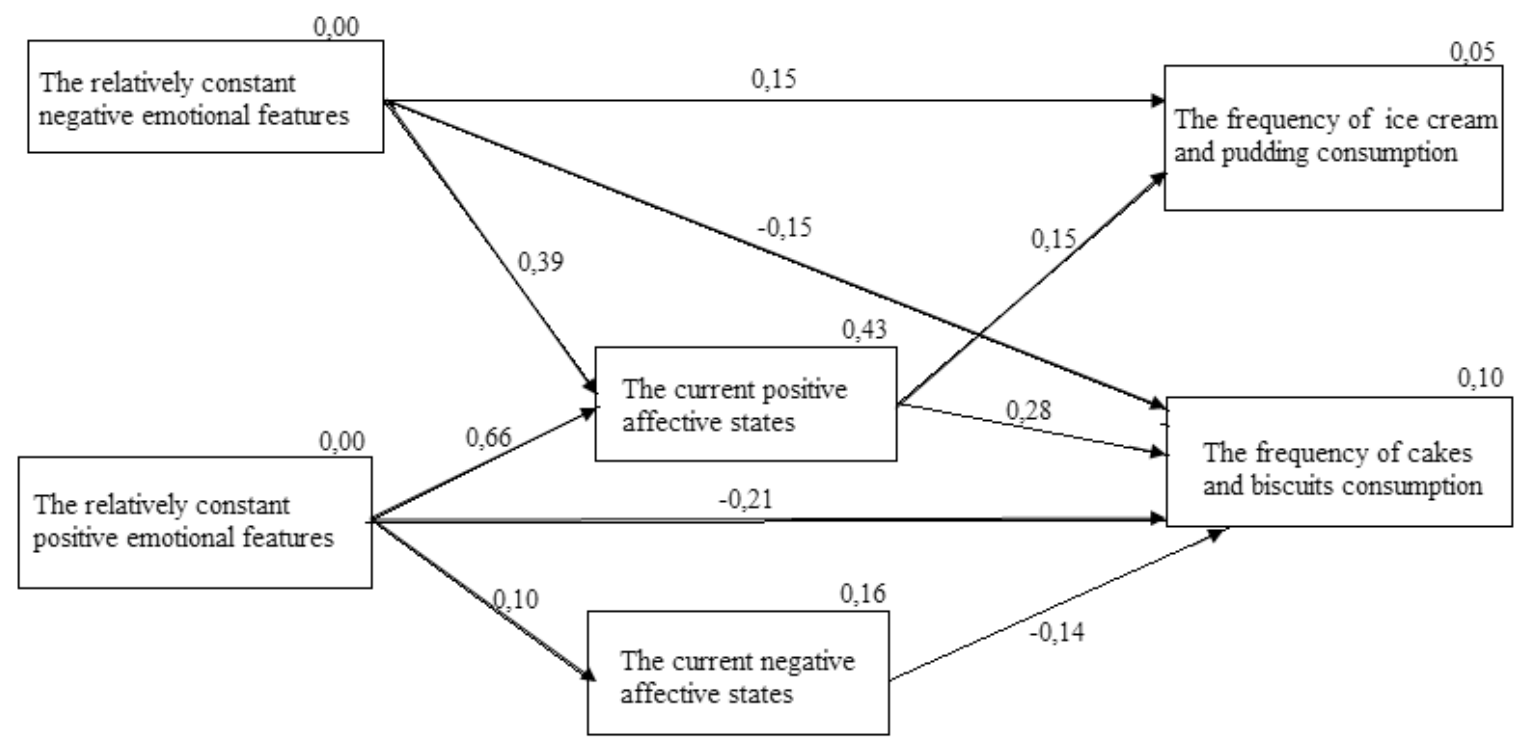

Figure 2. Model for women calculated based on the frequency ice cream and biscuits consumption (X 2 (6) $=4.080$, $p>.05$ $(p=0.666), C F I=1.000$ and RMSEA = 0.000; after removing statistically insignificant paths $)$.

The relatively constant negative emotional features among men have indirect positive and direct negative impact on the frequency of cakes and biscuits consumption. The relatively constant positive emotional features directly affect the current positive emotional state and indirectly on the frequency of ice cream and puddings consumption. The frequency of cakes and biscuits consumption were characterized by a direct positive impact on the frequency of ice cream consumption by men (Scheme 3). This observation was not seen in women.

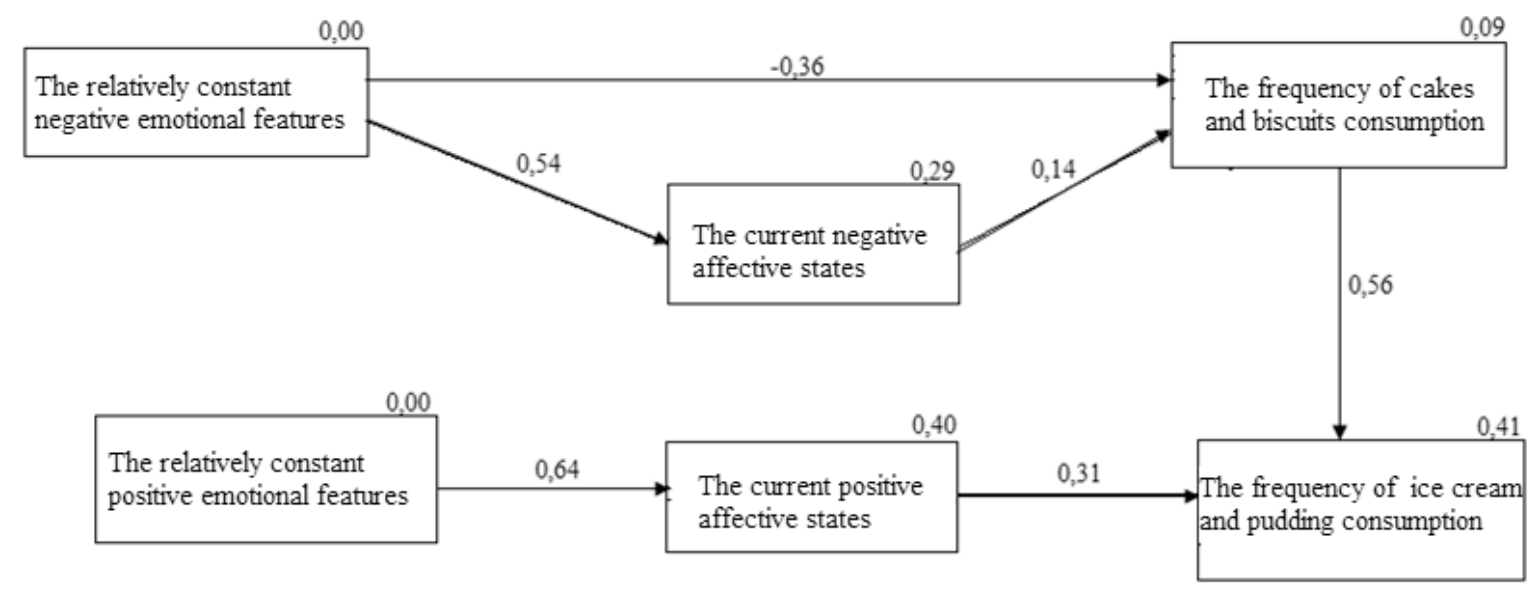

Figure 3. Model for wen calculated based on the frequency ice cream and biscuits consumption $(\chi 2(9)=7,066, p>.05$ $(\mathrm{p}=0.630) ; \mathrm{CFI}=1.000$ i RMSEA=0.000; after removing statistically insignificant paths).

\section{Discussion}

These research results confirmed the relation ship between current affective state and consumption of certain products groups containing carbohydrates - especially in simple sugars and glycogen. These dependences were observed in the case of ice cream, puddings, cakes and biscuits, which were noted in both women and men. The model equations analysis showed different mechanisms of the relationship between emotions (positive and negative) and consumption of products containing carbohydrates - simple sugars and glycogen - (for example, ice cream, cakes and biscuits) in terms of gender. Women were characterized by a more complex interrelationship between the emotional states and the emotional features relative to each other. Many psychological studies have shown differences between women and men in terms of emotional functioning in different areas of life [16].

The research in the field of food science have showed the existence of different volitional factors in the case of gender, which directly or indirectly are related to eating behaviour $[9,17,18]$. 
The problem of relationship between emotions with the consumption of food is very often studied area $[9,10,11]$. In presented study, it have showed that both positive and negative emotions are related to eating behaviour. These results undermine the commonly prevailing views on the so-called emotional eating. The literature often notes that the emotional eating is associated with the consumption of food under the influence of negative emotions such as sadness, anxiety, etc. $[12,19]$. The presented results of study indicate that food consumption is associated not only with negative emotions, but also with the positive emotions. In addition, positive and negative emotions are relative to each other in two different dimensions.

The innovation of this study is that relationship between positive emotional states and declared the consumption of foods containing carbohydrates - simple sugars and glycogen. Currently, these subjects were rarely discussed in the literature. The potential relationship between positive emotions and food consumption pointed out Cavallo \& Pinto [20] and Wolff et al [21].

The obtained results are in contrast to reports suggesting a direct relationship between emotions and consumption of chocolate. This observations were cited in the literature by Small et al. [22] and Ottley [23]. The discrepancies between these scientific reports can be explained by the fact that researchers did not ask respondents directly about the consumption of products containing carbohydrates - especially in simple sugars and glycogen - in the present study. Firstly, researchers have assessed affective state of respondents and then diet was analyzes. Perhaps organoleptic properties have a greater impact on the frequency of chocolate consumption than emotional states. Many studies have shown that sensory qualities of chocolate also can be an important motivating factor for the consumption of this product [24]. The lack of relationship between consumption of products containing chocolate with affective state can be an important area of potential therapeutic interactions, especially in the field of dietetics. This highlights the innovative and practical aspect of the present study.

It should be noted that there are scientific reports suggest a significant relationship between affective state and the ice cream consumption [25]. These results confirmed this relationship, too. The interesting observation was recorded using the method of structural equation. The relatively constant negative emotional features both directly and indirectly have influenced the frequency of ice cream consumption among women. The current positive emotions were characterized by a direct influence on the frequency of ice cream consumption. These observations were not recorded in the case of current negative emotional states. The positive current emotional states among men were characterized by a direct influence on the frequency of ice cream consumption. The relatively constant negative emotional features did not affect the frequency of consumption of ice cream among men.

The affective state had a significant relationship with the frequency of consumption of foods, such as biscuits and cakes. This relation was particularly important, especially in women. The frequency of cakes and biscuits consumptions among women were associated with a relatively constant emotional features (negative and positive) and current affective states (both positive and negative). This suggests that positive and negative emotions have a significant roles in the consumption of cakes and biscuits in women. The further studies should be conduct to clarify this mechanism in psychological and biological dimension.

The frequency of biscuits and cakes consumptions among men were associated with a relatively constant negative emotional features and current negative emotional states. The positive emotions were not characterized by the influence of the frequency of cakes and biscuits consumption among men.

Increased consumption of analyzed product groups can contribute to weight gain, and thereby lead to the development of overweight and obesity [3,4].

Characteristics of nutritional behaviour undertaken in terms of emotions should take into account three important factors:

1. Gender - The different observations were demonstrated for men and women in terms of eating behaviour;

2. The emotions severity, both positive and negative;

3. The nature of these emotions, ie, a relatively permanent emotional features or current emotional state. This study suggests further research in this three area.

Simultaneously, the presented results have some methodological limitations. These include: the small size of the group, purposeful selection of the respondents and only single measurement variables. This obtained results should be interpreted very cautiously bearing in mind these methodological limitations.

\section{Conclusions}

The current emotional status and relatively permanent emotional features show a significant relationship with the frequency of foods rich in carbohydrates - especially in simple sugars and glycogen - consumption of in both women and men. This demonstrated relationship may be applicable in the first degree prevention and clinical practice, but should take into account gender differences. 


\section{Acknowledgements}

Funding sources: Grant program for students associations by the Center for Active realized in 2012/2013.

\section{References:}

1. Widanagamage RD, Ekanayake S, Welihinda J. Carbohydrate-rich foods: glycaemic indices and the effect of constituent macronutrients. International Journal of Food Sciences and Nutrition. 2009; 60(4): 215-223.

2. Reeves SL, Henry CJ. Dietary change, energy balance and body weight regulation among migrating students. International Journal of Food Sciences and Nutrition. 2000; 51(6): 429-438.

3. Gibson S, Neate D. Sugar intake, soft drink consumption and body weight among British children: Further analysis of National Diet and Nutrition Survey data with adjustment for under-reporting and physical activity. International Journal of Food Sciences and Nutrition, 2007; 58(6): 445-460.

4. Gyntelberg F, Hein HO, Suadicani P, for the COPENHAGEN MALE STUDY. Sugar in coffee or tea and risk of obesity: A neglected issue. International Journal of Food Sciences and Nutrition.2009; 60(3): 56-64.

5. Niknam M, Saadatnia M, Shakeri F, Keshteli AH, Esmaillzadeh A. Consumption of sugar-sweetened beverages in relation to stroke: a case-control study. International Journal of Food Sciences and Nutrition. 2013; 64(1): $1-6$.

6. Ranawana V, Henry CJK. Liquid and solid carbohydrate foods: comparative effects on glycemic and insulin responses, and satiety. International Journal of Food Sciences and Nutrition. 2011; 62(1):71-81.

7. Mohindra NA, Nicklas TA, O'neil CE, Yang ST, Berenson GS. Eating patterns and overweight status in young adults: the Bogalusa Heart Study. International Journal of Food Sciences and Nutrition.2009; 60(3):14-25.

8. Hirasawa R, Yachi Y, Yoshizawa S, Horikawa C, Heianza Y, Sugawara A, et al. Quality and accuracy of Internet information concerning a healthy diet. International Journal of Food Sciences and Nutrition, 2013; 64(8): 1007-1013.

9. Franchi M. Food choice: beyond the chemical content. International Journal of Food Sciences and Nutrition, 2012; 63(1): 17-28.

10. Hartwell HJ, Edwards JSA, Brown L. The relationship between emotions and food consumption (macronutrient) in a foodservice college setting - a preliminary study. International Journal of Food Sciences and Nutrition. 2013; 64(3): 261-268.

11. Pasqui F, Baldini M, Biagi P, Maranesi M. Dietary habits and related psychological and social factors: Influence on the body weight of elementary school children. International Journal of Food Sciences and Nutrition, 2006; 57(3-4): 159-167.

12. Munsch S, Michael T, Biedert E, Meyer A.H, Margraf J. Negative mood induction and unbalanced nutrition style as possible triggers of binges in binge eating disorder (BED). Eating and Weight Disorders. 2008; 13: 22-29.

13. Watson D, Tellegen A. Toward a consensual structure of mood. Psychological Bulletin. 1985; 98: 219-235.

14. Brzozowski P. Skala uczuć pozytywnych i negatywnych SUPIN. Pracownia Testów Psychologicznych, warszawa 2010 (in Polish).

15. Wądołowska L. Validation of food frequency questionnaire (FFQ. Reproducibility assessment. Bromat. Chem. Toksykol. 2005; 38(1): 27-33.

16. Blanton RE, Chaplin TM, Sinha R. Sex differences in the correlation of emotional control and amygdala volumes in adolescents. Neuroreport. 2010; 21(14): 953-957.

17. Antúnez L, Vidal L, Sapolinski A, Giménez A, Maiche A, Ares G. How do design features influence consumer attention when looking for nutritional information on food labels? Results from an eye-tracking study on pan bread labels. International Journal of Food Sciences and Nutrition. 2013; 64(5): 515-527.

18. Ranilović J, Markovina J, Žnidar K, Barić IC. Attitudes to healthy eating among a representative sampling of Croatian adults: A comparison with Mediterranean countries. International Journal of Food Sciences and Nutrition. 2009; 60(7): 11-29.

19. Jansen A, Vanreyten A, van Balveren T, Nederkoorn C, Havermans R. Negative affect and cue-induced overeating in non-eating disordered obesity. Appetite. 2008; 51: 556-562.

20. Cavallo DA, Pinto A. Effects of mood induction on eating behavior and cigarette craving in dietary restrainers. Eating Behaviors. 2001; 2: 113-127.

21. Wolff GE, Crosby RD, Roberts JA, Wittrock DA. Differences in daily stress, mood, coping, and eating behavior in binge heating and non-binge heating college women. Addictive Behaviors. 2000; 25: 205-216.

22. Small DM, Zatorre RJ, Dagher A, Evans AC, Jones-Gotman M. Changes in brain activity related to eating chocolate. From pleasure to aversion. Brain. 2001; 124: 1720-1733. 
23. Ottley C. Food and mood. Nursing Standard, 2000; 15: 46-52.

24. Thabuis C, Cazaubiel M, Pichelin M, Wils D, Guerin-Deremaux L. Short-term digestive tolerance of chocolate formulated with maltitol in children. International Journal of Food Sciences and Nutrition. 2010; 61(7): 728738.

25. Van Strien T. Ice-cream consumption, tendency toward overeating, and personality. International Journal of Eating Disorders. 2000; 28: 460-464. 